\title{
Smoke and mirrors: how Massachusetts diverted millions in tobacco tax revenues
}

\author{
Wendy A Ritch, Michael E Begay
}

J Epidemiol Community Health 2002;56:522-528

See end of article for authors' affiliations

Correspondence to Michael E Begay PhD, Department of Community Health Studies, School of Public Health and Health Sciences, University of Massachusetts, $715 \mathrm{~N}$ Pleasant Street, 309 Arnold House, Amherst, MA 01003-9304, USA

begay.schoolph.umass.edu

Received 4 April 2000 and in revised form 1 October 2000. Accepted 20 August 2001

\begin{abstract}
Objective: This study examines the politics of appropriating Question 1 tobacco tax revenues in the first budget year after Massachusetts voters passed the ballot initiative in 1992. The initiative increased the tobacco tax on cigarettes by 25 cents per pack and on smokeless tobacco by $25 \%$ of the wholesale price.

Methods: Data were collected from newspapers, letters, memoranda, budgets, press releases, legislative floor debates, government documents, legislative journals, personal interviews, and tobacco industry documents that were downloaded from the Tobacco Archives internet site.

Results: During the first budget year, programmes mentioned by the initiative that were not exclusively tobacco related accounted for $27 \%$ of total Question 1 expenditures, while $50 \%$ of the revenues were allocated for programmes that were neither mentioned by the initiative nor provided any tobacco education, prevention, and cessation services. Only $23 \%$ of Question 1 funds were appropriated for programmes that provided exclusively tobacco education, prevention, and cessation services. Question 1 revenues were also used to supplant funding for pre-existing programmes, which was explicitly prohibited by the initiative. The first budget year became the template for Question 1 appropriations in subsequent fiscal years.

Conclusion: Politics did not end after voters passed Question 1. Public health advocates lacked a strategy and budget plan to influence the appropriation of Question 1 funds after the passage of this ballot initiative.
\end{abstract}

$\mathrm{T}$ he Massachusetts Coalition for a Healthy Future (MCHF), comprised of over 200 health organisations, and led by the Massachusetts Division of the American Cancer Society (ACS), campaigned for a 1992 ballot initiative to levy a new state tobacco tax to fund tobacco control programmes. ${ }^{12}$ This initiative, known as Question 1, raised the excise tax on cigarettes by 25 cents per pack and on smokeless tobacco by $25 \%$ of the wholesale price. Question 1 also created the Health Protection Fund (HPF), separate from the state's General Fund, for these new tobacco excise tax revenues. Although the Massachusetts constitution prohibits ballot initiatives from earmarking funds, the language of Question 1 provided the Legislature with a framework for spending HPF revenues.

Question 1 specified that revenues be used to incorporate information relating to the hazards of tobacco use into comprehensive school health education programmes; to fund workplace based and community smoking prevention and cessation programmes, as well as tobacco related public service advertising and drug education programmes; to support community health centres and their programmes of prenatal and maternal care, in order for these services to incorporate smoking cessation assistance and to provide guidance regarding the harmful effects of smoking on fetal development; and to monitor morbidity and mortality from cancer and other tobacco related illnesses. Question 1 also stated that the new revenues were to be used to supplement, not supplant, funding for existing programmes.

This paper examines the politics of appropriating tobacco tax revenues in the first budget year after Massachusetts voters passed Question 1 in 1992. The authors describe the budget process and primarily analyse decisions made by legislators and health organisations. This study shows that politics did not end after Question 1 was adopted.

\section{RESEARCH METHODS}

Data were collected from newspapers, letters, memoranda, budgets, press releases, legislative floor debates, government documents, legislative journals, personal interviews, and tobacco industry documents that were downloaded from the Tobacco Archives internet site (http:// www.tobaccoarchive.com).

\section{BUDGET POLITICS I: NOVEMBER 1992 TO MARCH 1993}

The day after the election, the ACS Director of Government Relations, Candace Pierce-Lavin, stated publicly that the MCHF would begin working with the Legislature to ensure that the new tobacco tax revenues would be spent as the public mandated. ${ }^{3}$ Once the election was won, the Coalition as a whole did not meet until mid March of 1993. However, the MCHF steering committee took on a great deal of responsibility for the Coalition's immediate post-passage activities.

ACS, with other Steering Committee members, started to work on Question 1 implementation several days after the initiative passed. Dr Blake Cady, the ACS President and the spokesperson for the Coalition, in November stated that any attempt by state legislators or administrators to use the new revenues to balance the budget would be a "breach of faith with the voters." ${ }^{4}$ Dr Cady stated that the Coalition would do "whatever it takes" to "keep them [the tobacco industry] away from the Health Protection Fund which is going to cost them their next generation of replacement smokers-our children." ${ }^{41}$

The MCHF Strategy Committee, which included Steering Committee member organisations as well as several other core Coalition member organisations, met in early November 1992 to discuss how they should participate in the budget process.

Reproduced in full with permission from Tobacco Control $2001 ; 10: 309-16$. 
Table 1 Question 1 budget proposals, 1993-94 fiscal year (in millions)

\begin{tabular}{ll}
\hline Original Department of Public Health (DPH) proposal & Nov 1992 \\
Comprehensive tobacco control programmes & $\$ 80.00$ \\
Comprehensive school health programme (to include smoking prevention) & $\$ 40.00$ \\
Total & $\$ 120.00$ \\
& Dec 1992 \\
Revised DPH proposal & $\$ 70.00$ \\
Comprehensive tobacco control programmes & $\$ 50.00$ \\
Comprehensive school health programme (to include smoking prevention) & $\$ 120.00$ \\
Total & \\
Hughes/DPH revised proposal & Jan 1993 \\
Tobacco education, prevention, and cessation activities & $\$ 70.00$ \\
Comprehensive school health programme (to include smoking prevention) & $\$ 40.00$ \\
Existing DPH programmes (to include smoking prevention) & $\$ 60.00$ \\
Total & $\$ 170.00$ \\
Massachusetts Coalition for a Healthy Future (MCHF) proposal & March 1993 \\
Tobacco education, prevention, and cessation activities & $\$ 54.50$ \\
School health expansion (to include smoking prevention) & $\$ 41.00$ \\
Existing DPH programmes (to include smoking prevention) & $\$ 10.00$ \\
Unallocated HPF revenues (for future tobacco control use) & $\$ 64.50$ \\
Total & $\$ 170.00$ \\
\hline Sources: Budget documents from DPH, MCHF, and DOE, 1992-93.
\end{tabular}

At this meeting it was decided that Coalition leaders would meet with legislators to discuss how to appropriate Question 1 funds, but the group did not adopt a concrete, post-campaign course of action. ${ }^{5}$ The next Strategy Committee meeting occurred in late January 1993. In the interim, the ACS acted as the primary Coalition contact.

\section{Department of Public Health budget plan}

The Department of Public Health (DPH) Commissioner, David Mulligan, drew up the first HPF budget in late November 1992 (table 1). This early budget plan proposed that $\$ 80$ million be spent for a comprehensive tobacco control programme through DPH and other departments within the Executive Office of Health and Human Services (EOHHS). DPH's budget proposal included funding for the anti-tobacco media campaign; workplace and community based initiatives; tobacco education, prevention, and cessation through health care providers and state substance abuse treatment programmes; and contracted research with local universities to evaluate the state's smoking reduction interventions. ${ }^{6}$ This proposal also allocated $\$ 40$ million for the comprehensive school health education programme through the Department of Education (DOE). ${ }^{6}$

In response to the DPH proposal, Candace Pierce-Lavin and Blake Cady asked in mid December for further clarification on a number of components, and demanded that a stronger emphasis be placed on youth smoking prevention and cessation. ${ }^{7}$ Pierce-Lavin and Cady also stated "it is essential to have a strong, independent tobacco control programme which can be tracked and measured" because while "tobacco control can be woven into some existing programmes, the majority of funds should be used for new tobacco control programmes and services." ${ }^{\prime 7}$ In its revised budget proposal, DPH called for "the cornerstone of the effort" to "prevent youth from smoking", with other efforts "directed at helping adults quit, particularly high risk groups from low income pregnant women to clients of human services agencies." ${ }^{8}$ This revised proposal was slightly different from the original plan, allocating \$70 million for comprehensive tobacco control programmes through DPH and EOHHS, and earmarking \$50 million for comprehensive school health education and other school health programmes through DOE (table 1 ). ${ }^{8}$

Coalition's spokesman endorsed the Hughes proposal In late January 1993, Robert L Hughes, President of the Massachusetts Association of Health Maintenance Organizations, authored a third version of DPH's Question 1 spending plan on behalf of the Coalition. The Hughes version stated in the opening paragraph that "the Coalition has had input in the plan's design, agrees with the concepts and is generally prepared to endorse it."'

The Hughes proposal called for the appropriation of $\$ 170$ million from the HPF but only specified that $\$ 70$ million be spent exclusively on new tobacco education, prevention, and cessation activities (table 1). It also proposed spending $\$ 40$ million for new and existing DOE comprehensive school health education programmes, such that "all should have a major emphasis on tobacco control." ${ }^{\prime \prime}$ In addition, \$60 million were to be allocated to expand existing DPH programmes to include smoking prevention components. The Hughes plan declared that Republican governor William Weld would submit a fiscal year (FY) 1993 Supplemental appropriation request of $\$ 70$ million in order to fund immediately new tobacco related services. The Hughes revision also established a "formula" for future funding reductions. It stated that, if budget decreases in HPF funded programmes were necessary, due to a decline or shortfall of revenues, "these decreases would be proportional among all new and existing expanded programmes [emphasis Hughes]."

\section{Coalition established a budget proposal review subcommittee}

In February 1993, in response to the Hughes plan, the Strategy Committee established the Tobacco Control Proposal Review Subcommittee. The subcommittee was charged with reviewing DPH and DOE budget proposals as well as with developing the Coalition's own Question 1 spending plan, because the Strategy committee did "not want to rely solely on the recommendations of the government agencies" but they did want to "spend as much money as reasonably possible on tobacco related efforts." ${ }^{10}$

At the 11 February meeting of the subcommittee, Richard Daynard, of Groups Against Smoking Pollution, shared a number of suggestions with the group. Members discussed establishing an evaluation programme that would be independent of DPH and DOE; funding tobacco related disease research grants; and conducting in-depth tobacco surveys, which measure the success of the Massachusetts Tobacco Control Program (MTCP), and would also assist with the task of goal setting. ${ }^{10}$ This subcommittee also considered using Question 1 revenues for nicotine patches; statewide competitive grants; education for health professionals to help 
themselves and their patients to quit smoking; a state, local, and corporate campaign against environmental tobacco smoke; smoking cessation for Medicaid and WIC programmes; and tobacco-free messages on shirts, sneakers, and signs at sporting events. ${ }^{10}$ In addition, Daynard suggested that any unspent funds should remain in the HPF for future use, since tax revenues would decrease as smoking rates decreased, while the tobacco industry would pour "millions into the state to counter [the MTCP's] efforts."10

\section{Agreement between the coalition's spokesman and the Weld administration}

Charles Baker, the Secretary of the Executive Office of Administration and Finance who negotiated with Dr Cady, recalled that Cady asked them to "set aside the first six months worth of funding just in case something happened", while Cady also consented to HPF spending "on a variety of other public health and prevention programmes, with the understanding that on a go-forward basis that stuff would be funded for the most part by General Fund money, and [Cady's] tobacco control programme [would] stay at about \$110 million. That worked for him." ${ }^{\prime 1}$

Secretary Baker understood that HPF revenues would be used specifically to sustain the state's tobacco control programmes, and any additional programmes that were funded out of the HPF in the first 18 months would need to be supported primarily with general funds in future years. ${ }^{11}$ According to Baker: "that's basically the deal we made, and that's certainly how we appropriated it. The next year, too. That's consistent with what Blake [Cady], David [Mulligan], and I agreed on." ${ }^{11}$ Cady thought that only the remaining $\$ 60$ million would be affected by the expected decline in revenues, and that the "\$110 million for solid tobacco control use would not be affected unless the revenues [fell] below \$110 million."'12 Cady believed that he had made a sensible compromise that would provide the MTCP with adequate funding for FY1993-94 of \$110 million, and with level funding for years to come.

Cady presented his agreement to the Strategy Committee in late February 1993. Concerned with its terms, "a majority of [the] members agreed that the agreement [that] was made was, although well-intentioned, wrong." ${ }^{13}$ The committee decided to inform the Weld administration that it had "re-thought" its position and was "moving forward . . with [its] own budget which will uphold the mandate of the voters to spend all of the money on tobacco related programmes and services."13

\section{BUDGET POLITICS II: MARCH 1993 TO JULY 1993 Supplemental FY 1993 budget}

The Coalition shifted its focus to the Legislature after Governor Weld submitted his Supplemental FY 1993 appropriations bill (table 2). The Strategy Committee had its own budget proposal that the coalition's general membership overwhelmingly had approved (table 1 ). ${ }^{14}$ The Coalition's proposal for the use of the first 18 months of Question 1 revenues directed that \$105.5 million of these funds be "dedicated strictly to tobacco control strategies, programmes and services" with the rest to "remain in the Health Protection Fund for use in later years when revenues decline due to expected decreases in smoking rates." ${ }^{14}$

The coalition began meeting with legislators in late March to lobby for its \$105.5 million 18 month HPF appropriations plan. On 31 March, Cady, Pierce-Lavin, and two other Coalition members met with Representative Brian Dempsey (Democrat, Haverhill) and Senator James Jajuga (Democrat, Essex). Reporting back to the Strategy Committee, Cady's assessment was that the meeting "was positive-the legislators support our budget. Senator Jajuga would like some money put into [the Executive Office of] Public Safety for enforcement of sales to minors. Everyone [seems to have] their own proposal of how the money should be spent."15 Senator Jajuga commented that "They had put together their budget, and they wanted their budget, and get out of their way, you know ... When Dr Blake Cady came in he was just sort of running [the budget proposal] by me. You know, just to give me a courtesy call. Running it by me? I was the one who was elected to make these sorts of decisions, along with 39 other senators and 160 representatives.." ${ }^{16}$

Senator Jajuga introduced an amendment to appropriate \$5 million for DARE (Drug Abuse Resistance Education) in the proposed FY 1993 Supplemental budget. ${ }^{16}$ DARE provides students with a knowledge base on the effects of drug abuse and teaches students refusal skills through role playing and other techniques. The controversy was that tobacco was a relatively small part of DARE's curriculum because it is considered a gateway drug. Senator Lois Pines (Democrat, Norfolk \& Middlesex) proposed language that specified that tobacco control must be a primary component of DARE. ${ }^{17}$ This language was adopted, and the DARE amendment passed the Senate. Coalition members were surprised and angered, and Senator Jajuga recalled that they publicly accused him of doing the bidding of the tobacco industry. ${ }^{16}$

A key member of the House was critical of the anti-tobacco media campaign. Representative Thomas Finneran (Democrat, Boston), then Chair of the House Ways and Means Committee, and later House Speaker, asked why so much money was going to television and radio advertisements when "money should be going to something more meaningful and more tangible in terms of peoples' health." ${ }^{18}$ Representative Finneran viewed the anti-tobacco media component as a waste of money because the evidence about the dangers of smoking was so overwhelming that "anybody who is smoking is smoking, and you can run ads until the cows come home, you're not going to affect a change in their behavior."'18

By mid-April, the House Ways and Means Committee passed its FY 1993 supplemental budget, which did not appropriate any Question 1 funds (table 2). In late April, Senate Ways and Means passed its FY 1993 supplemental budget that appropriated $\$ 20$ million from the HPF for the anti-tobacco media campaign (table 2). ${ }^{19}$ In early May, the Conference Committee, which met to resolve differences between the House and Senate Supplemental budgets, allocated \$14 million for the media campaign, \$5 million for DARE, and \$1 million to DOE's comprehensive school health education programme for new tobacco control services (table 2). ${ }^{20}$

The FY 1993 Supplemental budget was passed by the Legislature in mid May, and was signed by Governor Weld, but no carryover language for unspent funds was included in the budget. ${ }^{21}$ In the absence of a carryover provision, unspent Question 1 monies would revert back to the HPF, requiring them to be re-appropriated by the Legislature in FY 1994. A carryover provision was included in the governor's FY 1993 Supplemental appropriations bill. ${ }^{22}$

\section{Coalition lobbied legislators}

In the spring of 1993, coalition members continued to lobby legislators and monitor legislative support for their budget proposal. Supporters appeared to have adopted a nonconfrontational approach in their lobbying. This approach did not hold legislators accountable for their budget decisions. It may have weakened the Coalition's effort to ensure that Question 1 funds were spent on tobacco education and prevention programmes.

A pledge letter was sent to each legislator to be signed and returned to the Coalition, indicating his or her promise to support the MCHF's budget proposal. ${ }^{15}$ A press release was then sent out weekly, listing the names of the legislators who had signed the pledge letter. ${ }^{15}$ In order to involve the public in 
Table 2 Question 1 supplemental budget proposals, 1993 fiscal year (in millions)

\begin{tabular}{ll}
\hline Governor's Supplemental Budget Proposal & Jan 1993 \\
Comprehensive tobacco control programmes & $\$ 70.00$ \\
Total & $\$ 70.00$ \\
& \\
House Ways and Means Committee Proposal & April 1993 \\
Tobacco education, prevention and cessation activities & $\$ 0.00$ \\
Total & $\$ 0.00$ \\
& \\
Senate Ways and Means Committee Proposal & April 1993 \\
Anti-tobacco media campaign & $\$ 20.00$ \\
Total & $\$ 20.00$ \\
& \\
House/Senate Conference Committee Proposal & May 1993 \\
Anti-tobacco media campaign & $\$ 14.00$ \\
Drug Abuse Resistance Education (DARE) programme & $\$ 5.00$ \\
Comprehensive school health education programme & $\$ 1.00$ \\
Total & $\$ 20.00$
\end{tabular}

Sources: Budget documents from Fiscal Affairs, House Ways and Means Committee, Senate Ways and Means Committee, and House/Senate Conference Committee 1993.

grassroots political advocacy, an alert package was sent to interested Question 1 supporters to inform them of the Coalition's budget recommendations, and to ask them to call their legislators, write letters to the editor of their local newspapers, and attend the Question 1 Lobby Day in mid May. ${ }^{15}$

To assist the Coalition, Dennis Newman was hired as the MCHF lobbyist in early May. ${ }^{23}$ He lobbied legislators and administrators, reminding them that "one of the main arguments used against Question 1 [during the campaign] was that the money would not be spent for anti-smoking programmes, it would be used for other things." ${ }^{24}$ Newman worked closely with the Coalition, discussed lobbying strategies, and met primarily with members of the House and Senate Ways and Means Committees, as well as with the legislative leadership. ${ }^{24}$

\section{Tobacco industry activities}

Several years after his work on the Coalition's proposed FY 1994 budget, Newman felt that the Coalition was unsuccessful at realising one important goal-to keep the revenues that were not appropriated for tobacco control programmes in FY 1993-94 in the HPF for these programmes in future years, after the tobacco control programme's success triggered a decline in revenues. ${ }^{24}$ Newman also thought that the tobacco industry was successful in persuading the Legislature to appropriate Question 1 revenues for programmes that provided no tobacco control services. ${ }^{24}$ According to Newman, the tobacco industry "wanted a smaller programme and they wanted more of the tobacco control money spent on other public health programmes. We were successful in that year in particular because we got the $\$ 96$ million [but the tobacco industry's] success was that a lot of the remaining money was not held in reserve, it was spent on other programmes, deleting any reserve accounts." ${ }^{24}$

Newman, as well as several other political insiders, noticed a strong tobacco industry presence within the Legislature during the FY 1993-94 budget process. In fact, the tobacco industry spent approximately $\$ 550000$ to lobby the Legislature in 1993. ${ }^{25}$ Senator Thomas Birmingham (Democrat, Middlesex, Suffolk \& Essex), then Chair of the Senate Ways and Means Committee and later Senate President, recalled that tobacco industry lobbyists specifically "urged us to take all the money and spend it on anything but advertising and smoking cessation programmes [emphasis Birmingham]."26

Robert Gill, the legislative director for Senator Lois Pines, also recalled that the tobacco industry had a very active presence during the FY 1993-94 budget process. He said that they "held press conferences to urge legislators to appropriate the money [for non-initiative programmes]. For instance, their presence became most noticeable when the House began to debate the budget, and I think they were surprised at the outcome of the House debate, and became further mobilised after that point. They were fairly mobilised, and they were able to get a lot of phone calls in to legislators. They were in a fair amount of meetings, too." ${ }^{\prime 17}$ However, according to Cady, he and the Coalition did not have "any knowledge of any specific tobacco industry policy or programme, or behind the scenes work." ${ }^{27}$

In January 1993, American Tobacco reduced the prices of their top selling brands in Massachusetts by 50 cents per pack to undercut the new tobacco tax. ${ }^{28}{ }^{29}$ Philip Morris and RJ Reynolds followed suit in May. ${ }^{30}$ In addition, the Tobacco Institute, representing Philip Morris, RJ Reynolds, Brown $\delta$ Williamson, Lorillard, and American Tobacco, mounted a significant campaign against the new tobacco tax. A memo dated 3 December 1992 from Kurt L Malmgren, Senior Vice President of State Activities for the Tobacco Institute, outlined an extensive plan to undermine the implementation of Question $1 .^{31}$ A primary component of this strategy included encouraging legislators to target initiative monies to nontobacco related health programmes, such as indigent healthcare, prenatal services, and hospital emergency room support. ${ }^{31}$

\section{FY 1994 budget}

The Legislature began discussions in the spring of 1993 on Governor Weld's FY 1994 budget, which he submitted in late January (table 3). However, Weld only proposed spending $\$ 28.8$ million of Question 1 revenues for tobacco control purposes-\$18.8 million for smoking prevention programmes and $\$ 10$ million for cessation programmes. With the exception of his proposal to supplant $\$ 69.9$ million of General funds with HPF monies, the governor's January budget proposal was consistent with the Hughes plan. ${ }^{32}$

According to Senator Birmingham, advocates for noninitiative programmes did not request Question 1 funding. ${ }^{26}$ However, advocates for several of these programmes did make persuasive arguments linking their services with tobacco control. Senator Henri Rauschenbach (Republican, Cape $\delta$ Islands) was convinced of a connection between smoking and HIV infection by some activists who spoke during a Senate Ways and Means hearing in the late spring of $1993 .{ }^{33}$ As a result, the Legislature allocated over $\$ 9$ million of HPF revenues in FY 1994 for AIDS programmes. ${ }^{34}$

The fact that the Legislature supplanted, not supplemented, General funds with Question l funds for non-initiative programmes was a concern neither for most legislators nor for most recipient programmes. Robert Gill argued that it might 
Table 3 Question 1 regular and deficiency budget proposals, 1994 fiscal year (FY) (in millions)

\begin{tabular}{|c|c|}
\hline Governor's Budget Proposal & Jan 1993 \\
\hline Smoking prevention programmes & $\$ 18.80$ \\
\hline Tobacco cessation programmes & $\$ 10.00$ \\
\hline Subtotal of tobacco education and prevention activities & $\$ 28.80$ \\
\hline Supplantation of general funds with health protection fund (HPF) revenues & $\$ 69.90$ \\
\hline Total & $\$ 98.70$ \\
\hline House Ways and Means Proposal & June 1993 \\
\hline Tobacco education, prevention and cessation activities & $\$ 26.40$ \\
\hline Allocated for other public health programmes (non-tobacco control) & $\$ 92.60$ \\
\hline Total & $\$ 119.00$ \\
\hline Senate Ways and Means Proposal & June 1993 \\
\hline Tobacco education, prevention, and cessation activities & 76.00 \\
\hline Supplantation of general funds with HPF revenues (non-tobacco control) & $\$ 80.00$ \\
\hline Total & $\$ 156.00$ \\
\hline House/Senate Conference Committee Proposal & June 1993 \\
\hline Anti-tobacco media campaign (plus carryover from $1993 \mathrm{FY}$ ) & $\$ 6.00$ \\
\hline Department of Public Health (DPH) tobacco education, cessation, and prevention programmes & $\$ 13.00$ \\
\hline Department of Education (DOE) comprehensive school health programme (to include tobacco) & $\$ 22.00$ \\
\hline Comprehensive school health services (to include tobacco) & $\$ 3.00$ \\
\hline Subtotal of tobacco education, cessation, and prevention activities & $\$ 44.00$ \\
\hline Allocated for other public health programmes (non-tobacco control) & $\$ 79.00$ \\
\hline Total & $\$ 123.00$ \\
\hline Question 11994 FY Deficiency House/Senate Budget Proposal & July 1993 \\
\hline Tobacco education, prevention and cessation activities & $\$ 32.00$ \\
\hline Total & $\$ 32.00$ \\
\hline Question $11993 \mathrm{FY}$ and $1994 \mathrm{FY}$ Budget Allocations & Sept 1993 \\
\hline Supplemental $1993 \mathrm{FY}$ budget (for specific and related tobacco control activities) & $\$ 20.00$ \\
\hline $1994 \mathrm{FY}$ budget (for specific and related tobacco control activities) & $\$ 44.00$ \\
\hline $1994 \mathrm{FY}$ deficiency budget (for specific and related tobacco control activities) & $\$ 32.00$ \\
\hline Subtotal of specific and related tobacco education, cessation, and prevention activities & $\$ 96.00$ \\
\hline Allocated for other public health programmes (non-tobacco control) & $\$ 80.00$ \\
\hline Grand total & $\$ 176.00$ \\
\hline
\end{tabular}

Sources: Budget documents from Fiscal Affairs, House Ways and Means Committee, Senate Ways and Means Committee, and House/Senate Conference Committee 1993.

not be accidental that so many other "worthwhile" public health programmes, all of which existed before the creation of the HPF, were funded out of the HPF in FY $1994 .{ }^{17}$ Gill found that the pattern of spending that was established in FY 1993-94 created a "problematic conflict between the people who were lobbying for wonderful programmes in that they suddenly were becoming each others' enemies. It had the effect of pitting people against one another." ${ }^{17}$

\section{House budget plan for FY 1994}

By late May of 1993, the House Ways and Means Committee's budget proposal allocated $\$ 26.4$ million from the HPF for DPH and DOE tobacco related programmes (table 3). ${ }^{35}$ The Coalition urged representatives to support several amendments that would increase funding for tobacco control programmes. These amendments included a carryover provision that added $\$ 6$ million for the media campaign line item "provided further that prior appropriation [is] continued", moved to increase funding for DPH smoking prevention and cessation programmes to $\$ 20$ million, and increased DOE tobacco education programmes to almost $\$ 22$ million. ${ }^{36-38}$

Another amendment to the House FY 1994 budget proposed to use \$10 million of HPF monies for the Department of Medical Security's Healthy Kids Programme, which provides health insurance for children from economically disadvantaged families. ${ }^{20}$ Regarding this proposal, Senator Lucile Hicks (Republican, Middlesex) asserted, "they're betraying the voters' trust. It's a sneak attack by the tobacco industry so they can fight similar taxes in other states by pointing to Massachusetts' diversions."20 The Healthy Kids bill was enacted by the Legislature and was signed by Governor Weld. The House budget that was sent to the Senate in early June recommended that only $\$ 26$ million of HPF monies be spent on the state's tobacco education, prevention, and cessation programmes, while the remaining $\$ 93$ million were allocated to fund other non-initiative programmes. ${ }^{39}$

\section{Senate budget plan for FY 1994}

The Coalition asked the Senate to appropriate $\$ 6$ million for the media campaign, $\$ 34.5$ million for state and local tobacco control programmes through DPH, \$32 million for comprehensive school health education grants and other school initiatives through DOE, and \$10 million for comprehensive school health services through DPH. ${ }^{39}$ The Coalition's budget proposal to the Senate totalled \$82.5 million for FY 1994. Combined with the funds allocated in the FY 1993 Supplemental budget ( $\$ 20$ million), a grand total of $\$ 102.5$ million was proposed by the MCHF for the MTCP. The Coalition also proposed that the Senate leave any unappropriated Question 1 funds in the HPF for use by the MTCP in future years.

However, in June 1993 the Senate Ways and Means Committee allocated \$34 million of HPF revenues for tobacco control in FY 1994. This initial appropriation included \$6 million for the media campaign plus a carryover from FY 1993, $\$ 12$ million for tobacco control programmes through DPH, and \$16 million for tobacco related school health programmes and services through DOE. ${ }^{40}$ This represented an increase of only $\$ 8$ million over the House's budget proposal. Several state senators proposed an amendment to fund DPH's tobacco control programmes at a level of \$54 million for FY 1994, which included \$16 million for DOE's comprehensive school health education grants and \$6 million for comprehensive school health services.$^{41}$ Later, these same senators proposed that the $\$ 16$ million DOE appropriation for grants be included in a 
separate line item, so that $\$ 38$ million would be appropriated for DPH tobacco control programmes, which included \$6 million for comprehensive school health services. ${ }^{42}$ Additionally, they proposed to increase HPF funding to \$32 million for comprehensive school health education grants. ${ }^{43}$ One senator also sponsored an amendment to stop the Senate from supplanting General funds with HPF monies, but her amendment was defeated. ${ }^{44}$

In late June 1993, the Senate approved a \$76 million budget for tobacco education, cessation, and prevention programmes (table 3). Combined with the \$20 million FY 1993 Supplemental MTCP budget, the Senate budget allocated $\$ 96$ million of the new revenues for programmes related to tobacco control..$^{40}$ The remaining HPF monies, approximately $\$ 80$ million, were allocated for non-initiative programmes. ${ }^{40}$ Of the Senate's appropriation plan, Pierce-Lavin wrote, "the Coalition is thrilled with the Senate's action with Question 1 funds. With this level of funding, Massachusetts will soon be on the cutting edge of states aggressively working to eliminate the public health crisis created by tobacco addiction." ${ }^{40}$

\section{FY 1994 budget finalised}

By the end of June, the House-Senate Conference Committee approved a final FY 1994 MTCP budget of \$44 million and \$79 million of Question 1 funds for non-initiative programmes (table 3). This final FY 1994 budget contained \$6 million for the media campaign with a carryover provision for FY 1993 appropriations, \$22 million for DOE's comprehensive school health education programme, $\$ 13$ million for DPH's tobacco control programmes, and $\$ 3$ million for comprehensive school health services through DPH. The Conference Committee's MTCP budget of $\$ 44$ million passed the Legislature and was signed into law, yielding FY 1993-94 appropriations of \$64 million for tobacco specific and other initiative programmes.

However, the FY 1994 Deficiency budget was also being debated. The Deficiency budget is used to appropriate money for programmes in need of funding beyond that which was allocated for the regular fiscal year. In the second week of July, the House approved an amendment to the FY 1994 Deficiency budget which added $\$ 32$ million of HPF funds to the $\$ 44$ million appropriated for FY 1994 by the Conference Committee (table 3). ${ }^{45}$ The FY 1994 House Deficiency budget was also approved by the Senate and the Conference Committee. By the end of July the FY 1994 deficiency budget was passed in the Legislature and signed by the governor.

\section{Coalition's legislative success?}

At the end of the FY 1994 budget process, the MTCP was funded at a level of \$96 million for the 18 month FY 1993-94 budget cycle. Although the Coalition was not successful at preventing the Legislature from diverting HPF revenues to non-initiative programmes, Representative Finneran said that "the Coalition got close to, or maybe better than $90 \%$ of what it sought. Ninety-plus per cent from the legislative process is God-like. Moses himself could not have done any better." ${ }^{18}$

In the MTCP's FY 1993-94 budget of \$96 million (table 3), \$52 million were earmarked for tobacco specific programmes, while \$44 million were allocated for other initiative specified programmes. The remaining Question 1 revenues collected from l January 1993 through 30 June 1994-approximately $\$ 80$ million-were appropriated for non-initiative programmes such as AIDS, breast cancer, and others which were neither specified by the language of the initiative, nor promoted tobacco control activities. In addition $\$ 60$ million of these funds were used to supplant General funds for preexisting programmes, which was prohibited by the language of the initiative. ${ }^{25}$

\section{DISCUSSION}

Question I appropriations for FY 1993-94 set a precedent for the way these funds were allocated in future years. Although the Coalition had been very successful at campaigning to pass
Question 1, it was generally unprepared for an early, rigorous commitment to the Question 1 implementation process. One key factor that contributed to the diversion of Question 1 revenues during the first budget year was the coalition's lack of appropriate post-passage strategies and goals. Within two years after the initiative passed, the MCHF hired a lobbyist, a grassroots coordinator, and a media director to support its efforts. According to Pierce-Lavin and Lori Fresina of the ACS, "many difficulties could have been avoided had these people been in place at the end of the ballot initiative campaign" (Pierce-Lavin C, Fresina L, unpublished manuscript, March 1998).

After the MCHF defeated the $\$ 7.3$ million tobacco industry campaign against Question 1, the Coalition needed to recognise that it was now a major player in the state political arena. DPH stepped in to fill the void left by the Coalition's inaction by proposing various Question 1 spending plans. As a result, the Coalition adopted a reactionary instead of an offensive posture in the budget process. In addition, Dr Cady's early endorsement of the Hughes proposal approved of the diversion of HPF funds.

Question 1 diversions were also supported by some of the Coalition's member organisations. For example, the Massachusetts Medical Society and Blue Cross/Blue Shield championed the Healthy Kids Amendment for FY 1994. Pierce-Lavin recalled that "there were a lot of assumptions that [Coalition members ] . . wanted tobacco control to be the focus. What happened was everyone saw this huge pot of money, more than enough for tobacco control, so they began to give [some away to groups with] a cause.".46

\section{CONCLUSION}

Organisations that hope to pass and implement statewide initiatives may learn from the Massachusetts experience. What follows are some recommendations for coalitions:

- Develop legislative and lobbying strategies and a spending plan before the start of the budget process

- Hire lobbyists, grassroots organisers, and media coordinators during the initiative campaign, so they can immediately prepare and launch post-passage activities

- Establish a grassroots network comprised of interested and informed citizens to directly advocate with elected officials for tobacco control funding

- State that no one member of the coalition has the power to make agreements or act on behalf of the whole group without first obtaining approval from the leadership body

- Overestimate programme funding because the final budget will be less than that which is initially proposed

- Do not compromise early in the budget process

- Build an early warning network of friendly legislators and their staff to learn about industry activities in the budget process

- Inform voters and the media of legislative actions during the budget process

- Develop a political strategy to confront legislators or a governor who take positions or make decisions that threaten tobacco control funding

- Establish an independent initiative oversight committee to evaluate how funds are being spent and to recommend ways that revenues could be better spent

- Demand higher levels of funding every year, so programmes do not lose buying power because of inflation, and so they can provide more extensive services as client bases grow

- Do not forget that you won the election! Use the momentum from the campaign and the political power attained through the defeat of a multi-billion dollar industry to influence successfully the appropriations process. 


\section{What this paper adds}

Several studies have been published in recent years about campaigns to increase tobacco excise taxes in a variety of US states. However, little has been published on the complex network of political factors that influence how those monies are appropriated. This study focuses on that topic so that tobacco control advocates will know what to expect from the budget process, and can act accordingly.

In Massachusetts, the fight did not end when Question 1, a 1992 tobacco tax ballot initiative, was passed. Rather, seeing that Question 1 funds were appropriated as the voters had intended, for tobacco education, prevention, and cessation programmes, was a new battleground for many tobacco control advocates, who had little or no previous experience in the political sphere. The first budget year after the passage of a tobacco tax initiative is essential, since it may set a precedent for the way those revenues are appropriated in subsequent years. Therefore, this paper contributes to the existing literature by educating the public health community about the politics involved in the budget process, and by providing advocates with a number of recommendations to keep in mind when embarking on this long and arduous process.

The first budget year after the passage of a tobacco tax initiative is essential, since it may set a precedent for the way those revenues are appropriated in future years. Hopefully, when tobacco control advocates in other states participate in the budget process, their political activity will be informed by the experiences of their colleagues in Massachusetts.

\section{ACKNOWLEDGEMENTS}

This research was supported by a grant from the American Cancer Society (RPG-97-033-01-PBR) and by a grant from the National Institutes of Health (1 R01 CA86314-01). Opinions expressed reflect the views of the authors and do not necessarily represent the sponsoring agencies, the School of Public Health and Health Sciences at the University of Massachusetts Amherst or the School of Public Health at the University of Medicine \& Dentistry of New Jersey.

\section{Authors' affiliations}

W A Ritch, University of Medicine \& Dentistry of New Jersey, School of Public Health, Health Systems and Policy Division, New Brunswick, New Jersey, USA

M E Begay, University of Massachusetts Amherst, School of Public Health and Health Sciences, Department of Community Health Studies, Amherst, Massachusetts, USA

\section{REFERENCES}

1 Heiser PF, Begay ME. The campaign to raise the tobacco tax in Massachusetts. Am J Public Health 1997:87:968-73.

2 Koh H. An analysis of the successful 1992 Massachusetts tobacco tax initiative. Tobacco Control 1996;5:220-5.

3 Question 1 backers set to hustle "yes" vote into antismoking action. Boston Globe. 5 November 1992.

4 Question 1 Group Issues Warning. Boston Globe. 20 November 1992

5 Massachusetts Coalition for a Healthy Future. Strategy committee meeting agenda. 12 November 1992.

6 David Mulligan to Charles Baker. Proposal for Proposition 1 revenues. 24 November 1992.

7 Candace Pierce-Lavin and Blake Cady to David Mulligan. Regarding the DPH proposal for Question \#1 funding. 15 December 1992.
8 David Mulligan to Charles Baker. Revised proposal for Proposition 1 revenues. 18 December 1992

9 David Mulligan to Charles Baker. Administration's plan for Question \# 1 revenues. 21 January 1993

10 Massachusetts Coalition for a Healthy Future. Tobacco contro proposal review committee meeting minutes. 11 February 1993.

11 Interview with Charles Baker. 23 January 1998.

12 Candace Pierce-Lavin to Field Staff. Use of Question \#1 funds. 22 February 1993

13 Massachusetts Coalition for a Healthy Future. Strategy committee meeting minutes. 25 February 1993.

14 Candace Pierce-Lavin to Field Staff. New Question 1 budget proposal. 24 March 1993

15 Massachusetts Coalition for a Healthy Future. Strategy committee meeting minutes. 31 March 1993.

16 Interview with James Jajuga. 12 January 1998

17 Interview with Robert Gill. 16 December 1997.

18 Interview with Thomas Finneran. 16 December 1997.

19 Candace Pierce-Lavin to Field Staff. Question 1 update and lobby day. 26 April 1993

20 Two Major players break ranks on how to use the cigarette tax. Boston Globe. 10 May 1993

21 Massachusetts Coalition for a Healthy Future. Strategy committee meeting minutes. 28 April 1993.

22 The Commonwealth of Massachusetts. House No. 2735. 16 February 1993

23 Massachusetts Coalition for a Healthy Future. Strategy committee meeting minutes. 10 May 1993.

24 Interview with Dennis Newman. 26 July 1995

25 Lucile Hicks. Senate floor debates on the FY 1995 budget. Boston. 14 June 1994

26 Interview with Thomas Birmingham. 9 January 1998

27 Interview with Blake Cady. 26 July 1995

28 Radazzo D. The American Tobacco Company Agency action memo regarding approval recommendation for Massachusetts tax buster. Revised 4 January 1993

29 Mr JM Clark to Mr EA Pape. Regarding recommendation Massachusetts tax buster. 4 December 1992.

30 Tobacco price cutting spurs sales, group says. Boston Globe. 3 July 1993.

31 Malmgren KL. KLM remarks for the 12/10 executive committee meeting. 3 December 1992. Case ID: 1004026. American Tobacco Company Document Collection.

32 Weld maps \$70M smoking fight. Boston Globe. 22 February 1993.

33 Interview with Henri Rauschenbach. 24 February 1998

34 The Commonwealth of Massachusetts. A Joseph Denucci, State Auditor. No. 95-5027-3, State auditor's report on the additional tobacco tax imposed by chapter 254 of the Acts of 1992, "An Act pertaining to health and tobacco." Boston. 1997.

35 Massachusetts Coalition for a Healthy Future and the American Cancer Society to House Representatives. Regarding the Hayward Amendment. 27 May 1993.

36 Hayward, Marzilli, and Gardner. Move to Amend H.5200, Item 4500-1010. May 1993.

37 Hayward, Marzilli, and Gardner. Move to Amend H.5200, Item 4590-0300. May 1993

38 Hayward, Marzilli, and Gardner. Move to Amend H.5200, Item 7040-1000. May 1993.

39 Massachusetts Coalition for a Healthy Future and the American Cancer Society to Massachusetts State Senators. Regarding the FY94 Senate budget for the Massachusetts tobacco control program. 6 June 1993.

40 Candace Pierce-Lavin and Sharon Stade to ACS Staff, Coalition Members and Question 1 Supporters. Regarding good news about the Senate budget and the next step. 24 June 1993.

41 Pines, Hicks, and Melconian. Move to Amend Senate no. 1994, Item 4590-0300. June 1993.

42 Pines, Hicks, and Melconian. Move to Amend Senate no. 1994, Item 4590-0300. June 1993.

43 Pines, Hicks, and Melconian. Move to Amend Senate no. 1994, Item 7032-0500. June 1993.

44 Hicks. Move to Amend Senate no. 1994, Items 4510-01 10, 4513-1000, 4513-1002, 4513-1005, 4513-1111, 4518-0100, 4570-1500, 4512-0103, 4512-0200. June 1993.

45 Candace Pierce-Lavin and Sharon Stade to Question 1 Supporters, ACS Staff, and Coalition Members. Regarding the deficiency budget. 19 July 1993

46 Interview with Candace Pierce-Lavin. 19 March 1998. 